\title{
Giant otter Pteronura brasiliensis density and abundance in Llanos Orientales de Colombia in the Orinoco basin
}

\author{
Germán Garrote, Beyker Castañeda, Jose Manuel Escobar, Laura Pérez \\ Brayan Marín, Jacinto Terán and Fernando Trujillo
}

\begin{abstract}
The giant otter Pteronura brasiliensis, categorized as Endangered on the IUCN Red List, was once widely distributed throughout South America. By the middle of the 2oth century the giant otter had become locally extinct along the main rivers of the Orinoco basin. Although some populations seem to have recovered, the paucity of information available does not permit a full evaluation of the species' conservation status. The objective of this study was to estimate the abundance and density of the giant otter population along the Orinoco river in the municipality of Puerto Carreño, Vichada, Colombia, where there is important commercial and recreational fishing. Thirty-nine linear $\mathrm{km}$ were surveyed, repeatedly, with a total of $315 \mathrm{~km}$ of surveys. Population size was estimated by direct counts of individuals. All individuals detected were photographed and identified individually from their throat pelage patterns. In total, 30 otters were identified, giving a minimum density of 0.77 individuals per $\mathrm{km}$, one of the highest reported for the species in Colombia. Given the high density in this well-developed area, our results highlight the importance of this population for the conservation of the species.
\end{abstract}

Keywords Colombia, density estimation, giant otter, Orinoco river, Pteronura brasiliensis, survey

The giant otter Pteronura brasiliensis, categorized as Endangered on the IUCN Red List (Groenendijk et al., 2015), was once widely distributed throughout South America from northern Argentina to Colombia and Venezuela (Carter \& Rosas, 1997). However, because of the commercial value of its fur, overhunting in the $1950 \mathrm{~s}$ and 196os led to the collapse of its populations and extinction over a large part of its original range (Carter \& Rosas, 1997). In the 1960 in Llanos Orientales de Colombia (Orinoco Basin) the species was present only in the remote upper reaches of the rivers (Medem, 1968). More recent

GERmÁn GarRote (Corresponding author, (D) orcid.org/0000-0002-6974-4513), Jose Manuel Escobar and Laura Pérez Instituto de Biología de la Conservación (IBiCo), c/ Neblí, 13. 28230, Madrid, Spain

E-mail gergarrote@gmail.com

Beyker Castañeda, Brayan Marín, Jacinto Terán and Fernando Trujillo Fundación Omacha, Bogotá, Colombia

Received 16 May 2019. Revision requested 13 September 2019.

Accepted 9 January 2020. First published online 25 November 2020. studies have shown that the species is now present throughout the area (Carrasquilla, 2002; Díaz, 2007). However, the methods used in these studies did not provide information that permits an evaluation of the species' conservation status. Our objective therefore was to estimate the abundance and density of the giant otter population along the Orinoco river, and its tributaries and lagoons, in the municipality of Puerto Carreño, in Vichada, Colombia.

This study was carried out along the Orinoco river in the municipality of Puerto Carreño in the north-east of the Department of Vichada (Fig. 1). This department lies at altitudes of 50-100 $\mathrm{m}$, has a mean annual temperature of $28^{\circ} \mathrm{C}$, and the mean total annual precipitation is $2,176 \mathrm{~mm}$, with dry (December-March) and rainy (April-November) seasons (IGAC, 1996). The study area includes the Bojonawi private nature reserve, and lies in the El Tuparro Biosphere Reserve. Important commercial and recreational fishing activities occur in this area.

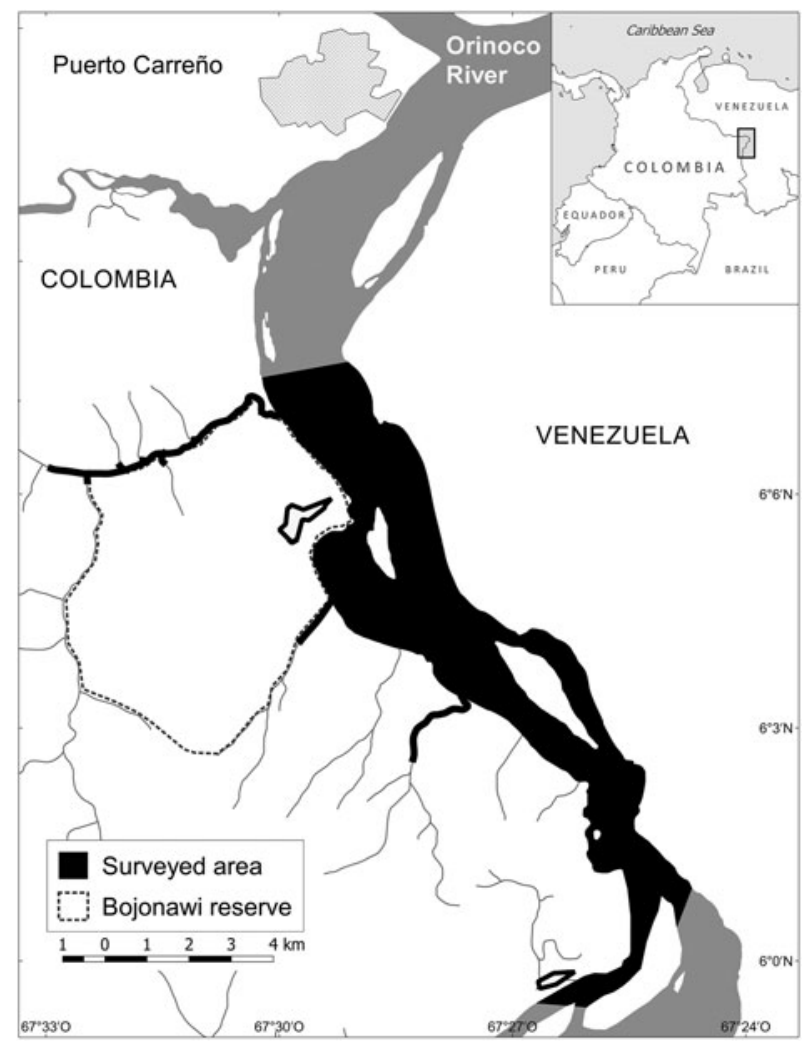

FIg. 1 The study area in eastern Colombia, showing river sections and lagoons surveyed. 
TABLE 1 The six sectors surveyed for the giant river otter Pteronura brasiliensis in Colombia (Fig. 1), with type of water body, survey method, length of each sector, number of surveys of each sector, and total survey effort.

\begin{tabular}{lllccc}
\hline Wector & $\begin{array}{l}\text { Water } \\
\text { body }\end{array}$ & Method & $\begin{array}{l}\text { Length } \\
(\mathrm{km})\end{array}$ & $\begin{array}{c}\text { No. of } \\
\text { surveys }\end{array}$ & $\begin{array}{l}\text { Total } \\
\text { effort } \\
(\mathrm{km})\end{array}$ \\
\hline Orinoco & $\begin{array}{l}\text { Principal } \\
\text { river }\end{array}$ & Boat & 21.30 & 9 & 191.70 \\
San José & Tributary & Foot & 2.40 & 5 & 12.00 \\
Tesoro & Tributary & Foot & 2.10 & 4 & 8.40 \\
Negro & Tributary & Boat & 11.20 & 8 & 89.60 \\
India & Lagoon & Canoe & 0.70 & 10 & 7.00 \\
Pañuelo & Lagoon & Canoe & 1.17 & 5 & 5.85 \\
Total & & & 38.87 & 41 & 314.55 \\
\hline
\end{tabular}

Giant otters are territorial, diurnal, live in groups and have irregular pale patterning on their throats that allows individuals to be identified (Duplaix, 1980), facilitating estimation of population size by direct counts of groups and individuals (Groenendijk et al., 2005). Given the logistical impossibility of sampling continuously, the area was divided into six sectors, which were sampled independently (Table 1). Depending on accessibility, each sector was sampled using either a 9-m motorized aluminium boat with a 25 -hp engine or a canoe, or on foot along the banks of streams where access by boat was impossible. Surveys were conducted by three experienced observers during 7.3018.oo. When we detected an individual or group of otters, we followed them until the pale throat patterns of each individual could be photographed and the size of the group established. We recorded group sizes and locations using a GPS, which we also used to calculate the length of each transect. The surveys were carried out during 15 January-9 March 2018 during the dry season, when the otters are easiest to detect (Groenendijk et al., 2005).

The study area comprised a total of 38.87 linear $\mathrm{km}$, including the main river, its tributaries and lagoons. Each sector was sampled repeatedly, giving a total survey effort of 314.55 linear $\mathrm{km}$ (Table 1). Six groups of giant otters and two solitary individuals were detected. The groups consisted of 2-11 individuals, with a mean of $4.67 \pm$ SD 3.39 individuals per group. In total, 30 otters were identified, yielding a minimum density of 0.77 individuals per $\mathrm{km}$.

Our results show that the giant otter density along the river Orinoco and its tributaries and lagoons in the Puerto Carreño area is among the highest reported for the species in Colombia (Table 2), similar to the 0.8 individuals per $\mathrm{km}$ in the Apaporis river in the Amazon Basin (Botello, 2000) and greater than the 0.17 individuals per $\mathrm{km}$ in the Inirida Fluvial Star and the tributaries of the upper Orinoco river (Suarez, 2010). Compared to elsewhere in South America, the density we recorded is similar to the highest densities reported for the species in the Brazilian Pantanal (0.74-1.00 individuals per $\mathrm{km}$; Tomas et al., 2015) but lower than in the river San Martín in Bolivia (3.87 individuals per km; van Damme et al., 2002) and Suriname (1.2 individuals per km; Duplaix, 1980). However, the latter two areas are remote,

TABLE 2 Compilation of studies of the giant otter, with length of water body surveyed (effort) and density of individuals observed.

\begin{tabular}{|c|c|c|c|c|}
\hline Country & Study area & $\begin{array}{l}\text { Survey effort } \\
(\mathrm{km})\end{array}$ & $\begin{array}{l}\text { Density } \\
\text { (individuals per } \mathrm{km} \text { ) }\end{array}$ & Source \\
\hline Colombia & Orinoco-Bojonawi & 39 & 0.77 & This study \\
\hline Colombia & Inirida Fluvial Star, Guaviare & 217 & 0.17 & Suárez (2010) \\
\hline Colombia & Caño Limón, Arauca & 39 & 0.17 & Armas \& Padilla (2010) \\
\hline Colombia & Río Apaporis, Amazonas & 30 & 0.83 & Botello (2000) \\
\hline Bolivia & Río Verde, Noel Kempff National Park & 22 & 0.09 & Fraser et al. (1993) \\
\hline Bolivia & Río Paucerna, Noel Kempff National Park & 46 & 0.20 & Fraser et al. (1993) \\
\hline Bolivia & Río Itenez Guaporé, Noel Kempff National Park & 225 & 0.12 & Fraser et al. (1993) \\
\hline Bolivia & Río Paragua, Noel Kempff National Park & 291 & 0.26 & van Damme et al. (2001) \\
\hline Bolivia & Río Negro & 168 & 0.26 & Painter et al. (1994) \\
\hline Bolivia & Río San Martín, Itenez Reserve & 23 & 3.87 & $\begin{array}{l}\text { Ten (unpubl. data, 2001), } \\
\text { in van Damme et al. (2002) }\end{array}$ \\
\hline Bolivia & Río Itenez Guaporé, Itenez Reserve & 45 & 0.89 & $\begin{array}{l}\text { Ten (unpubl. data, 2001), } \\
\text { in van Damme et al. (2002) }\end{array}$ \\
\hline Bolivia & Río Madidi, Madidi National Park & 21 & 0.18 & Ayala \& Wallace (2009) \\
\hline Brazil & Río Aquidauana, Pantanal & 324 & 0.30 & Tomas et al. (2015) \\
\hline Brazil & Canal Riozinho, Pantanal & 23 & 0.74 & Tomas et al. (2015) \\
\hline Brazil & Río Negro, Pantanal & 36 & 1.00 & Tomas et al. (2015) \\
\hline Brazil & Jauaperi river, Xixuaú Reserve, Roraima & 40 & 1.00 & Evangelista \& Rosas (2011) \\
\hline Peru & del Manu National Park & 179 & 0.22 & Mendoza et al. (2017) \\
\hline Peru & Las Piedras & 309 & 0.05 & Mendoza et al. (2017) \\
\hline Peru & Los Amigos & 116 & 0.04 & Mendoza et al. (2017) \\
\hline Suriname & & & 1.20 & Duplaix (1980) \\
\hline
\end{tabular}


with few people. Otters occur in lower densities in areas where they are killed by fishers, or prey is scarce because of poor river productivity or overfishing (Trujillo et al., 2015).

The Orinoco is a highly productive river with high fish densities (Lasso et al., 2010) and consequently supports healthy giant otter populations. Nevertheless, this abundance of fish in an accessible area close to a population centre also encourages fishing. During our study, we identified at least eight fishers' camps on the rivers Orinoco and Caño Negro, and the city of Puerto Carreño is host to c. 1,ooo recreational fishers every fishing season (December-March). Given that killing by fishers is one of the main threats to this otter throughout much of its range (Rosas, 2004; Recharte et al., 2009; Trujillo et al., 2015), we would expect this to occur in a popular fishing area. However, a study carried out amongst fishers in Puerto Carreño in 2018 indicated that $93 \%$ believed that otters were not harmful to fishing activity (Garrote, 2019).

Nevertheless, there is pressure on fish stocks: both the number of fish caught and their mean size have fallen significantly since 2000 (Trujillo et al., 2015). This could potentially lead to a decrease in the carrying capacity for the giant otter, and to increased competition between otters and fishers, jeopardizing the positive perception that fishers have of this species (Lavigne, 1997). Further threats to the species in the Puerto Carreño area include the illegal trade of skins and the capture of cubs as pets (Cruz Antía et al., 2010; Trujillo et al., 2015).

Given the high density of the giant otter in this welldeveloped area, our results highlight the importance of this population for the conservation of the species. We will continue to monitor this population, seeking to improve our understanding of the dynamics driving the relative high density and the fishers' favourable perception of the species.

Acknowledgements This study was carried out within the framework of the project 'Population monitoring and strategies for the conservation of the giant otter (Pteronura brasiliensis) in the Bojonawi Reserve', funded by the Fundación Barcelona Zoo and Ayuntamiento de Barcelona.

Author contributions Study conception and design: GG, FT; data collection and analysis: GG, BC, JME, LP, JT, BM; writing: all authors.

\section{Conflicts of interest None.}

Ethical standards This research abided by the Oryx guidelines on ethical standards.

\section{References}

Armas, E. \& Padilla, A. (2010) Estudio Poblacional: Distribución, Abundancia y Caracterización Acuática del Hábitat del Perro de Agua (Pteronura brasiliensis) en el Área de Caño Limón y su
Zona de Influencia. Technical report, Corporinoquia, Arauca, Colombia.

Ayala, G. \& Wallace, R. (2009) Giant otter (Pteronura brasiliensis) distribution and abundance at Alto Madidi, Parque Nacional Madidi, La Paz, Bolivia. Revista Boliviana de Ecología y Conservación Ambiental, 25, 41-49.

Botello, J.C. (200o) Ecología y comportamiento del lobo del río (Pteronura brasiliensis) la región del bajo río Apaporis, Amazonía Colombiana. BSc thesis, Universidad del Valle, Cali, Colombia.

Carrasquilla, M.C. (2002) Uso de habitat, comportamiento y dieta de la nutria gigante (Pteronura brasiliensis) en el río Orinoco. BSc thesis, Universidad de los Andes, Bogotá, Colombia.

Carter, S. \& Rosas, F.C.W. (1997) Biology and conservation of the giant otter, Pteronura brasiliensis. Mammal Review, 7, 1-26.

Cruz-Antia, D. \& Gómez, J.R. (2010) Aproximación al uso y tráfico de fauna silvestre en Puerto Carreño, Vichada, Colombia. Ambiente y Desarrollo, 26, 63-94.

Díaz, D.L. (2007) Uso de hábitat de nutria gigante Pteronura brasiliensis en segmentos d elos rios Bita y Orinoco en el área de influencia de Puerto Carreño (Colombia). BSc thesis, Universidad Nacional de Colombia, Bogotá, Colombia.

Duplaix, N. (1980) Observations on the ecology and behaviour of the giant river otter (Pteronura brasiliensis) in Suriname. Revue d'Écologie, 34, 496-620.

Evangelista, E. \& Rosas, F.C.W. (2011) The home range and movements of giant otters (Pteronura brasiliensis) in the Xixuaú Reserve, Roraima, Brazil. IUCN/SSC Otter Specialist Group Bulletin, 28, 31-37.

Fraser, A., Barret, J., Marsh, A., Smith, K. \& Stipale, J. (1993) Giant Otters in the Noel Kempff Mercado National Park. Technical report. Nottingham University, Nottingham, UK.

Garrote, G. (2019) Conservación de la Nutria Gigante (Pteronura brasiliensis) en la Reserva Bojonawi y Río Orinoco (Vichada, Colombia). Technical report. Instituto de Biología de la Conservación, Fundación Omacha, Fundación Barcelona Zoo, Madrid, Spain.

Groenendijk, J., Duplaix, N., Marmontel, M., van Damme, P. \& SCHENCK, C. (2015) Pteronura brasiliensis, Giant otter. In The IUCN Red List of Threatened Species 2015: e.T18711A21938411. dx.doi.org/ 10.2305/IUCN.UK.2015-2.RLTS. T18711A21938411.en [accessed 6 March 2020].

Groenendijk, J., Hajek, F., Duplaix, N., Reuther, C., van Damme, P., SCHENCK, C. et al. (2005) Surveying and monitoring distribution and population trends of the giant otter (Pteronura brasiliensis)_Guidelines for a standardisation of survey methods as recommended by the giant otter Section of the IUCN/SSC Otter Specialist Group. Habitat, 16, 1-10o.

IGAC (1996) Aspectos Ambientales para el Ordenamiento Territorial del Municipio de Mitú, Tomo I. International Global Atmospheric Chemistry, Santa Fe de Bogotá, Colombia.

Lasso, C., Usma, J.S., Trujillo, F. \& Rial, A. (2010) Biodiversidad de la Cuenca del Orinoco: Bases Científicas para la Identificación de Áreas Prioritarias para la Conservación y Uso Sostenible de la Biodiversidad. Instituto de Investigaciones Biológicas Alexander von Humboldt, WWF Colombia, Fundación Omacha, Fundación La Salle e Instituto de Estudios de la Orinoquia (Universidad Nacional), Bogotá, Colombia.

Lavigne, D.M. (1997) Ecological interactions between marine mammals, commercial fisheries, and their prey: unravelling the tangled web. Oceanographic Literature Review, 44, 3-229.

Medem, F. (1968) Exterminación de la Fauna en los Llanos Orientales de Colombia Universidad Nacional de Colombia. Universidad Nacional de Colombia, Bogotá, Colombia. 
Mendoza, J.A., Huamani, K., Sebastian, G. \& Ochoa, J.A. (2017) Giant Otter (Pteronura brasiliensis) distribution and population status in Madre de Dios River basin, southeastern Peru. Revista Peruana de Biología, 24, 155-162.

Painter, R.L.E. (ed.), Arias Cossió, S., Cox, G., Rebolledo, R., Rumiz, D., Tapia Arauz, C. \& Wallace, R. (1994) Anexo 3. La fauna de la Reserva de Vida Silvestre de los ríos Blanco y Negro: distribución, diversidad, densidad y pautas para su conservación. In Plan de Manejo Reserva de Vida Silvestre de ríos Blanco y Negro. Fundación Amigos de la Naturaleza and Wildlife Conservation Society, La Paz, Bolivia.

Recharte, M., Bowler, M. \& Bodmer, R. (2009) Potential conflict between fishermen and giant otter (Pteronura brasiliensis) populations by fishermen in response to declining stocks of arowana fish (Osteoglossum bicirhossum) in Northeastern Peru. IUCN Otter Specialist Group Bulletin, 25, 89-93.

Rosas, F.C.W. (2004) Ariranha, Pteronura brasiliensis (Carnivora: Mustelidae). In História Natural, Ecologia e Conservação de Algumas Espécies de Plantas e Animais da Amazônia (ed. R. Cintra), pp. 265-269. Instituto Nacional de Pesquisas da Amazônia, Manaus, Brazil.
SuÁrez, J.P. (2010) Evaluación de uso de hábitat de la nutria gigante Pteronura brasiliensis, asociado a problemas de conservación en el río Inírida. BSc thesis, Universidad Militar Nueva Granada, Bogotá, Colombia.

Tomas, W.M., Camilo, A.R., Ribas, C., Leuchtenberger, C., Borges, P.A.L., Mourão, G. \& Pellegrin, L.A. (2015) Distribution and conservation status of giant otter Pteronura brasiliensis in the Pantanal wetland, Brazil. Latin American Journal of Aquatic Mammals, 10, 107-114.

Trujillo, F., Caro, A., Martínez, S. \& Rodríguez-Maldonado, M.V. (2015) Negative interactions between giant otters (Pteronura brasiliensis) and local fisheries in the Amazon and Orinoco basins in Colombia. Latin American Journal of Aquatic Mammals, 10, 122-130.

van Damme, P.A., Michels, H., Delaunoy, Y., Saravia, J.L., Swaenepoel, K.Y.O. \& Jongeneelen (2001) La Londra Pteronura brasiliensis en el Río Paraguá. Technical report. Cochabamba, Bolivia. van Damme, P.A., Ten, S., Wallace, R., Painter, L., Taber, A., Gonzales Jimenes, R. et al. (2002) Distribution and population status of the giant otter Pteronura brasiliensis in Bolivia. Revista Boliviana de Ecología y Conservación Ambiental, 12, 111-134. 